\title{
Interannual Variation of Larval Fish Assemblages in the Gulf of Cádiz (SW Iberian Peninsula) in Relation to Summer Oceanographic Conditions
}

\author{
Paulo Mafalda Júnior ${ }^{1 *}$ and Juan Perez de Rubín ${ }^{2}$ \\ ${ }^{1}$ Universidade Federal da Bahia - UFBA; Instituto de Biologia; Laboratório de Plâncton; 40.210-020; \\ pomafa@ufba.br; Salvador -BA - Brasil. ${ }^{2}$ Instituto Español de Oceanografía - IEO; Muelle pesquero, s/n; apdo \\ 285,29640,jprubin@ma.ieo.es; Fuengirola - MA - España
}

\begin{abstract}
Two ichthyoplankton surveys were conducted during July 1994 and July 1995 in the Gulf of Cádiz with the aim of describing composition, abundance, distribution patterns and interannual variations of larval fish assemblages. Interannual differences were found in this study. In 1994, higher salinities were observed at external sites, though in 1995, higher values were observed at intermediate sites. The upper water column was warmer in 1994 and had less fish larvae density. During 1994, Sardinella aurita and Engraulis encrasicolus were abundant but spatial location was opposite. In 1995, abundance of both species was very different, but with similar spatial pattern. Cluster analysis revealed well-defined groups of stations and assemblages of larvae, primarily related to bathymetry. The "inshore assemblage" occupied the shallow coast area; its characteristics species being closely related to the estuarine system, mainly comprising Engraulis encrasicolus and Gobiidae. The "shelf assemblage" occupied the continental shelf and its characteristics species consisted of larvae whose adults inhabited the shelf province and spawn in the same zone, like Sardinella aurita and Trachurus spp. Interannual variations in composition and extension of the subgroups could be attributed to the main circulation patterns, continental water discharge and spawning strategies of fishes.
\end{abstract}

Key words: Larval fish assemblages, Sardinella aurita, Engraulis encrasicolus, Gulf of Cádiz

\section{INTRODUCTION}

An ichthyoplankton assemblage is by definition transient because it is restricted to the egg and larval phases. However, the multiespecies larval associations may be adaptive and result from similar responses among species to the pelagic environment (Frank and Legett, 1983; Somarakis et al., 2000). Interannual variability in the assemblage of fish larvae might trace the variation in physical processes and be particularly useful in highlighting shared or contrasting adaptations of species to the pelagic environment (Somarakis et al., 2002). Thus, the distribution and abundance patterns of fish larvae can contribute significantly to an understanding of the biology and ecology of fish populations (Doyle et al., 2002).

Yet, attention to this matter in the Gulf of Cádiz has been limited despite it supports large, economically valuable fisheries resources, and provision for nursery areas for many fish species (Rodrigues-Roda, 1970, 1977; Garcia and Moyano, 1991; Rubín et al., 1999). Preliminary results were published for the global area (Rubín

\footnotetext{
${ }^{*}$ Author for correspondence
} 
et al., 1997, 1999; García et al., 2002) and the interannual changes were only studied for some neritic sectors of the Gulf of Cádiz (Salmerón and Rubín, 1997a,b). These studies provide a starting point but do not reflect the interannual variability in the composition and structure of ichthyoplanktonic groups.

This paper presents results of the first meso-scale multiespecies larval fish investigation in the Gulf of Cádiz. It involves the definition of early summer larval fish assemblages, their composition, the dominant species, the major distributions patterns, both across and along the continental shelf, and the principal characteristics of the water column that control this patterns.

\section{STUDY AREA}

The Gulf of Cádiz strategically located connecting the open Atlantic Ocean with the Mediterranean Sea, through the Strait of Gibraltar (Fig. 1), has been scarcely studied, particularly from the viewpoint of physical-biological coupling (García et al., 2002). The area of the Gulf of Cádiz is characterized by an ample continental shelf, around $50 \mathrm{~km}$ wide, except at the west of the Guadiana river, where it has only $130 \mathrm{~m}$ of wide (Abrantes, 1990). The most important rivers are the Guadalquivir and the Guadiana and the continental runoff reach the lowest values in summer (Garcia and Moyano, 1991). Temperature distribution and dynamic topography indicate the existence of anticyclonic circulation following the bottom contours running from NW to SE (Stevenson, 1977; Folkard et al., 1997; García et al., 2002). When prevailing winds in the Gulf are from the west, an upwelling area is found east of Cape Santa María in Portugal (Folkard et al., 1997). The upwelled waters form a cold tongue that separates from the coast and flows offshore in the SW direction, towards the Strait of Gibraltar. The "Huelva Front" separates this colder water from warmer waters of the central part of the gulf (Vargas et al., 2003). Stevenson (1977) describes the "Huelva Front" as a warm-cold-warm frontal structure running in the SE-NW direction offshore, approximately between the cities of Cádiz and Huelva. Another upwelling area is also evident at the southwest of the Strait of Gibraltar (Vargas et al., 2003).

\section{MATERIAL AND METHODS}

During July 8 to 15,1994 and July 10 to 17,1995 , a regular sampling grid of 35 stations was occupied in the Gulf of Cádiz (Fig. 1). Each station consisted of a CTD cast plus ichthyoplankton hauls. A Bongo net, with $40 \mathrm{~cm}$ diameter (Rubín, 1992), equipped with two independent flowmeters and one depth meter gauge was employed to carry out "double-oblique" trawls from the surface to $100 \mathrm{~m}$ depth. The samples obtained were preserved in $5 \%$ buffered formalin.

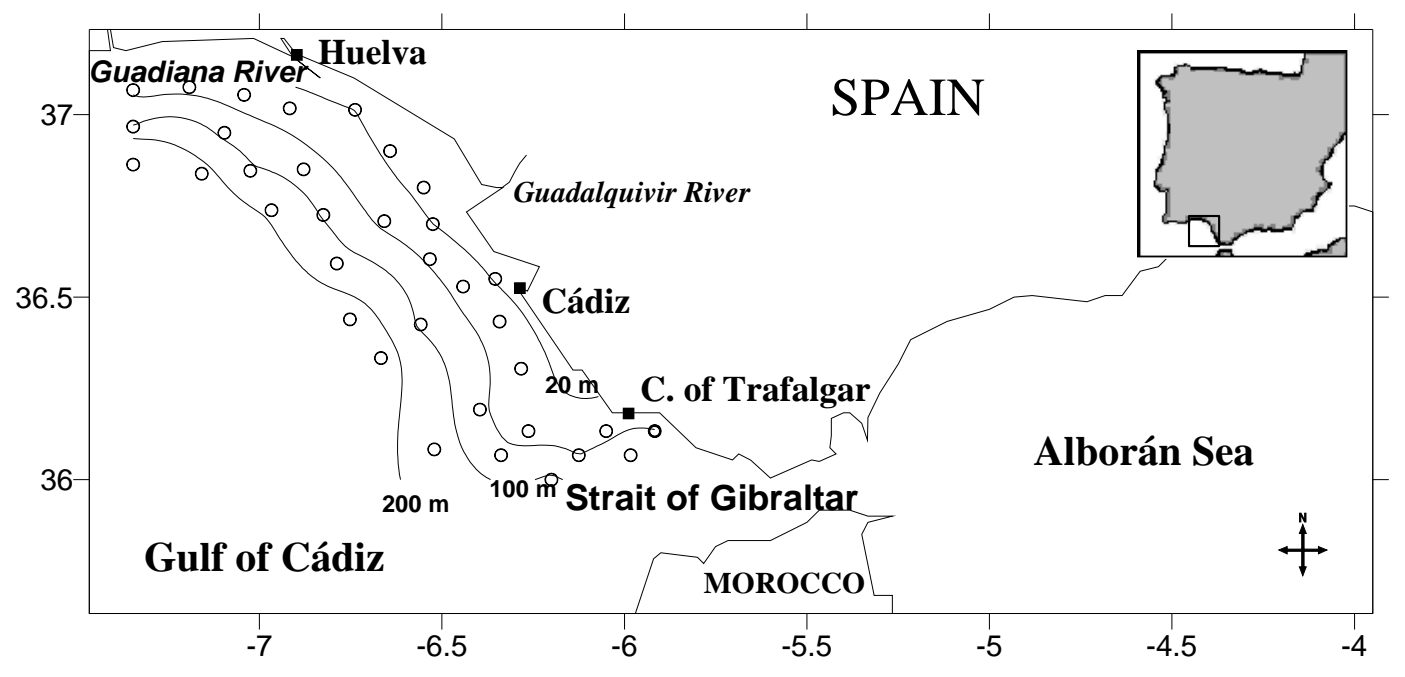

Figure 1 - Study area showing bathymetry and the sampling stations. 
Zooplankton displacement volume (ZDV) was measured for each sampling site from the catch of the $250 \mu \mathrm{m}$ mesh bongo net (Ahlstrom and Thrailkill, 1963). ZDV values were standardized to $\mathrm{ml}$ per $\mathrm{m}^{3}$. Material collected with $335 \mu \mathrm{m}$ mesh net were used to make the taxonomic identification of the ichthyoplankton. The number of fish larvae and eggs collected was standardized to $10 \mathrm{~m}^{2}$ (Smith and Richardson, 1979). Fish larvae were identified to the lowest possible taxonomic level and grouped into three categories, "demersal", "epipelagic" and "mesopelagic", according adult fish habitat.

\section{Data analysis}

Interannual differences in the abundance of different taxa were tested using the non-parametric Wilcoxon Test (Siegel, 1982). Similarity among sampling sites and taxa were measured using Manhattan distances and were grouped by the Ward's method (Pielou, 1984) to produce dendrograms. Prior to analysis, logarithmic transformation $\ln (x+1)$ of the larval abundance $(x)$ was performed to homogenize the variance (Taylor, 1961). In this analysis, were included only those eleven taxa that contributed more than $0.5 \%$ of the total abundance in both two years. The relationship between water depth, ZDV, salinity, temperature, fish larvae, taxa number and station groups from the cluster analysis was explored by performing non-parametric Kruskal-Wallis Test (Siegel, 1982) using median among station groups for each cruise. Post-hoc pairwise multiple comparisions of median among station groups were also performed.

\section{RESULTS}

\section{Environmental Conditions}

Rubín et al. (1997; 1999) described the environmental conditions of two oceanographic surveys and only a brief summary was presented there. The water column was generally well stratified and the thermocline was located at a mean depth of $20 \mathrm{~m}$. Due to mesoescale variability, the termocline depth varied, having a tendency to move downward in anticyclonic area in the slope and continental shelf, in front of Cádiz Bay.

During these two years, warmer temperatures (22 $23^{\circ} \mathrm{C}$ ) were observed at the inshore sites of the
Cádiz Bay and Huelva, at the area north. Southern area, in front of the Cape of Trafalgar, was generally cooler than the rest of surveyed area. Yet, at the offshore sites, the north area was cooler than the south area. In 1994, higher salinities (> 36.4 ups) were observed at the north area and offshore, though in July 1995, higher values were observed around Cádiz bay.

\section{Taxonomic composition and abundance of fish larvae}

A total of 16 taxa (Table 1) were identified (13 taxa in 1994 and 16 taxa en 1995). Furthermore, the interannual differences between taxa number were not significant $(p>0.05)$. Mean larvae density was higher $(\mathrm{p}<0.01)$ in $1995(0-12610$ larvae. $10 \mathrm{~m}^{-2}$, average $\left.=1962\right)$ than $1994(0-1920$ larvae. $10 \mathrm{~m}^{-2}$, average $=768.5$ ). The abundance of demersals fish (Gobiidae, Labridae, Sparidae, Callionymus spp., Serranus spp, Cepola rubescens and Arnoglossus spp ) was similar between the two years $(p>0.05)$, and Gobiidae was the demersal dominant taxa. Larvae of different pelagic species (i.e. Sardinella aurita, Trachurus spp. and Capros aper) were more abundant in the 1995 collections ( $\mathrm{p}<0.05)$, but anchovy (Engraulis encrassicolus) was more abundant in 1994 (Table I).

\section{Individual species distribution}

Several demersal taxa, such as Gobiidae, Labridae, Sparidae, Callionymus spp., Arnoglossus spp, Cepola rubescens and pelagics species, such as, Trachurus spp and Capros aper did not show any marked interannual differences in their horizontal distribution (however their abundance might have been different between the two years, e.g. the abundance of pelagics). Although larvae of demersal Serranus spp "shift" from inshore area to continental shelf area your abundance was equal between years $(\mathrm{p}>0.05)$.

Anchovy larvae, Engraulis encrassicolus, and gilt sardine larvae, Sardinella aurita, showed interannual differences $(\mathrm{p}<0.05)$ in their abundance and horizontal distribution. During 1994, for both species were abundant (> 400 larvae. $10 \mathrm{~m}^{-2}$ ) but spatial location was opposite. Gilt sardine larvae appeared in a neritic station at the north sector (surface temperature $=22.5^{\circ} \mathrm{C}$ ). Whereas, the maximum abundances of larvae of anchovy have been located south of Cádiz, in warmer waters $\left(>23^{\circ} \mathrm{C}\right)$. On the other hand, in 1995 abundance of both species was very different 
(gilt sardine: 4000 to 6000 larvae.10 $\mathrm{m}^{-2}$; anchovy 200 to 300 larvae. $10 \mathrm{~m}^{-2}$ ), but with similar spatial pattern (middle shelf off Cádiz, $22^{\circ} \mathrm{C}$ ).

\section{Comparison of sampling sites}

Cluster analysis of sampling sites produced three distinct groups in 1994 and 1995 (Fig. 2). Group 1 comprised inshore sites, group 2 (intermediate) and 3 (external) were predominantly continental shelf stations. The Kruskal-Wallis Test (Table 2) using water depth shows a significant station group effect $(\mathrm{p}<0.001)$. The pair-wise comparison of means shows that station group 3 located at the mid-shelf was significantly different from all other stations groups at the $1 \%$ level. In both years (Table 2), the inshore sites presented the major ZDV values ( $\mathrm{p}<0.001$ ). In 1994 (Table 2 ), the major salinity values were found at external sites $(\mathrm{p}<0.0001)$ but, in 1995 , they were located at intermediate sites $(\mathrm{p}<0.05)$. The temperature (Table 2) was similar between stations groups in 1994 ( $p$ > 0.05). In 1995, the major temperature values were located at the intermediate sites $(\mathrm{p}<$ $0.05)$.

\section{Larval assemblages}

Eleven taxa were abundant in both year collections and were used to ecological classification. Three groups of species were defined in the two years. They correspond to the station groups identified in the clustered analysis of sampling sites. Species present in these groups integrated into well defined assemblages, named "inshore" and "shelf" which were generally persistent in their respective zones (Fig. 3).

INSHORE ASSEMBLAGE: Probably influenced by riverine inputs (Rubín et al., 1999), occupied mainly the shallow stations (Group 1).

The sector occupied by this assemblage varied throughout the years. In 1994, it comprised the area from Guadiana river mouth to the Cape of Trafalgar, in depths less than $40 \mathrm{~m}$. In 1995, the area was smaller, extending from Guadiana river mouth to Cádiz, in depth less than $28 \mathrm{~m}$. In 1995 (Table 2), this assemblage presented less taxa ( $<$ < $0.001)$ and larvae density $(\mathrm{p}<0.001)$.

Table 1 - List of larval fish taxa identified, their taxa ecology (D - demersal, EP - epipelagic, MP - mesopelagic), relative abundance $(\mathrm{A} \%)$, frequency of occurrence $(\mathrm{F} \%)$, mean density $\left(\mathrm{X}=\right.$ larvae $\left.10 \mathrm{~m}^{-2}\right)$ and their code in the Cluster analysis.

\begin{tabular}{|c|c|c|c|c|c|c|c|c|}
\hline \multirow[b]{2}{*}{ Taxa } & \multirow[b]{2}{*}{ Origin } & \multicolumn{3}{|c|}{1994} & \multirow[b]{2}{*}{ Code } & \multicolumn{3}{|c|}{1995} \\
\hline & & $\mathbf{A} \%$ & F\% & $\mathbf{X}$ & & $\mathrm{A} \%$ & $\mathbf{F \%}$ & $\mathbf{X}$ \\
\hline GOBIIDAE & $\mathrm{D}$ & 19,03 & 88,6 & 147,8 & GOB & 9,57 & 94,1 & 179,5 \\
\hline LABRIDAE & $\mathrm{D}$ & 14,80 & 91,4 & 120,8 & LAB & 7,00 & 79,4 & 141,6 \\
\hline Engraulis encrassicolus & $\mathrm{EP}$ & 14,18 & 68,6 & 112,0 & ENG & 3,86 & 82,4 & 72,2 \\
\hline SPARIDAE & $\mathrm{D}$ & 11,90 & 80,0 & 88,9 & SPA & 6,19 & 88,2 & 125,2 \\
\hline Callionymus spp. & $\mathrm{D}$ & 8,00 & 74,3 & 57,3 & CAL & 4,04 & 82,4 & 78,1 \\
\hline Serranus sp & $\mathrm{D}$ & 5,78 & 71,4 & 46,9 & SER & 4,43 & 61,8 & 92,2 \\
\hline Sardinella aurita & $\mathrm{EP}$ & 4,88 & 45,7 & 33,9 & SAR & 33,66 & 58,8 & 671,7 \\
\hline Cepola rubescens & $\mathrm{D}$ & 3,10 & 42,9 & 23,4 & CEP & 3,72 & 67,6 & 72,7 \\
\hline Arnoglossus spp. & $\mathrm{D}$ & 2,34 & 60,0 & 16,6 & $\mathrm{ARN}$ & 2,62 & 64,7 & 52,0 \\
\hline Trachurus spp. & $\mathrm{EP}$ & 1,10 & 31,4 & 6,9 & TRA & 1,65 & 44,1 & 31,9 \\
\hline Capros aper & MP & 0,60 & 22,9 & 4,0 & CAP & 1,58 & 50,0 & 29,4 \\
\hline BLENNIIDAE & $\mathrm{D}$ & 0,54 & 22,9 & 5,0 & - & 0,35 & 32,4 & 7,4 \\
\hline ACHIRIIDAE & $\mathrm{D}$ & 0,25 & 17,1 & 2,1 & - & 1,37 & 26,5 & 22,7 \\
\hline Cyclothone sp & MP & 0,00 & 0,0 & 0,0 & - & 0,08 & 8,8 & 2,1 \\
\hline Hipросатрus sp. & $\mathrm{D}$ & 0,00 & 0,0 & 0,0 & - & 0.01 & 2,6 & 0,3 \\
\hline Mullus surmuletus & $\mathrm{D}$ & 0,00 & 0,0 & 0,0 & - & 0.01 & 2,6 & 0,3 \\
\hline
\end{tabular}



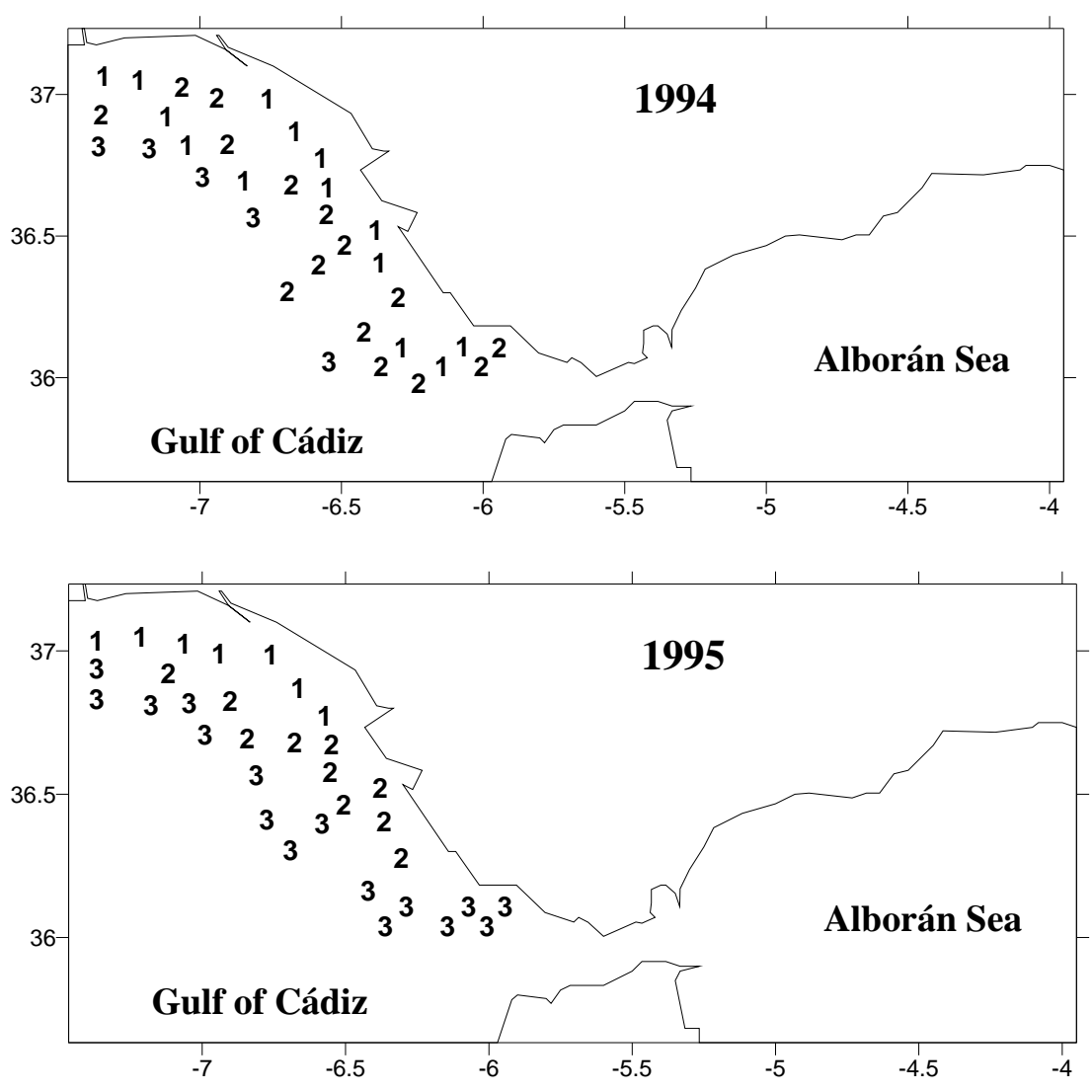

Figure 2 - Geographic distribution of station groups defined by cluster analysis. 1, Inshore sites; 2, Intermediate sites; 3, External sites.

Table 2 - Averages and standard deviation for depth (m), ZDV (ml. $\left.\mathrm{m}^{-3}\right)$, salinity (ups), temperature $\left({ }^{\circ} \mathrm{C}\right)$, fish larvae density (larvae. $10 \mathrm{~m}^{-2}$ ) and number of taxa in larval fish assemblages.

\begin{tabular}{|c|c|c|c|c|c|c|}
\hline \multirow[t]{2}{*}{ Assemblage } & \multicolumn{3}{|c|}{1994} & \multicolumn{3}{|c|}{1995} \\
\hline & Inshore & Intermediate & External & Inshore & Intermediate & External \\
\hline Depth & $40.2+/-28.5$ & $77.6+/-56.0$ & $221.8+/-118.8$ & $2.8 .2+/-11.1$ & $47.3+/-26.3$ & $136.6+/-112.4$ \\
\hline ZDV & $28.9+/-20.2$ & $16+/-8.8$ & $3.6+/-1.1$ & $24,6+/-12.3$ & $22.8+/-9.8$ & $12.4+/-3.6$ \\
\hline Sal & $36.29+/-0.05$ & $36.33+/-0.05$ & $36.41+/-0.06$ & $36.23+/-0.04$ & $36.38+/-0.16$ & $36.23+/-0.1$ \\
\hline Temp & $22.27+/-0.80$ & $22.35+/-0.81$ & $21.80+/-0.80$ & $21.37+/-0.57$ & $21.84+/-0.92$ & $20.70+/-0.64$ \\
\hline Density & $428+/-288$ & $1198+/-549$ & $27.9+/-34.8$ & $376+/-206$ & $4609+/-4175$ & $1119+/-939$ \\
\hline Taxa & $7.4+/-1.8$ & $10.3+/-1.3$ & $2+/-1.6$ & $5.3+/-0.8$ & $10.3+/-1.8$ & $9.3+/-1.6$ \\
\hline
\end{tabular}

The taxa characterizing this assemblage included demersals (Gobiidae, Labridae, Sparidae and Callionymus spp.) and anchovy (Engraulis encrassicolus). The between-year differences involved a "shift" of Serranus spp larvae from inshore to shelf assemblage, in 1995.

SHELF ASSEMBLAGE: Predominantly occupied this continental shelf stations in depths upper than $100 \mathrm{~m}$. It had two subgroups, variable in extension between years. They were orientation from the coast to the ocean, and were designated as intermediate shelf assemblage and external shelf assemblage. The intermediate shelf assemblage comprised inner shelf group of stations (Group 2) and was characterized by the epipelagic species (Sardinella aurita and Trachurus spp). 
1994

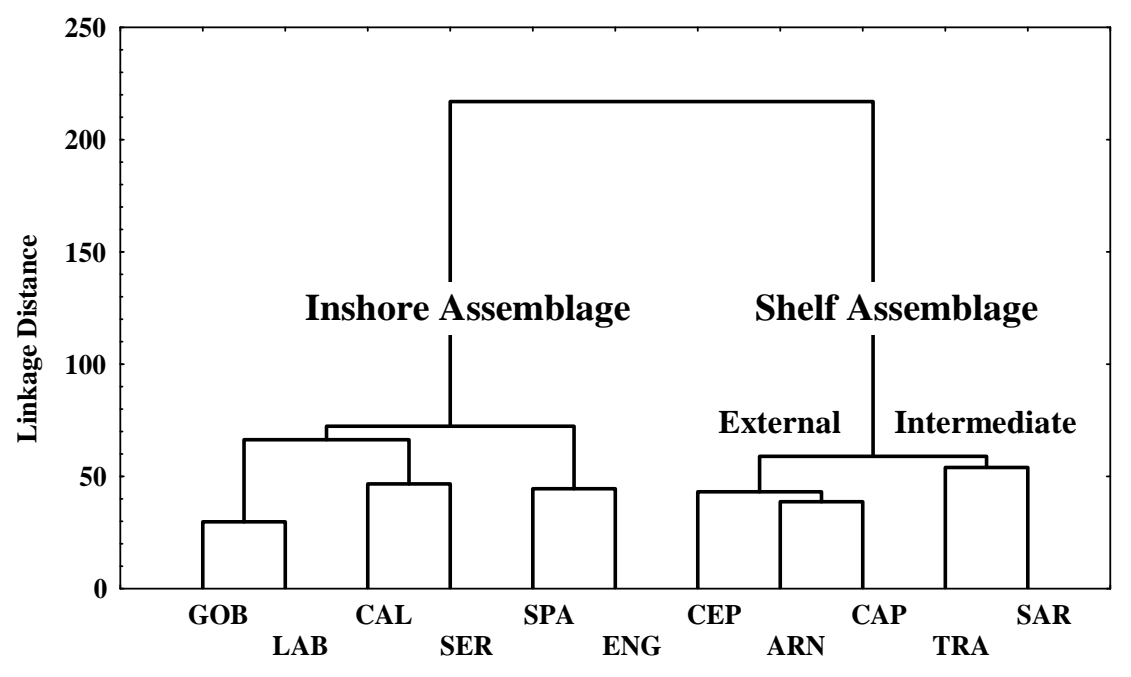

1995

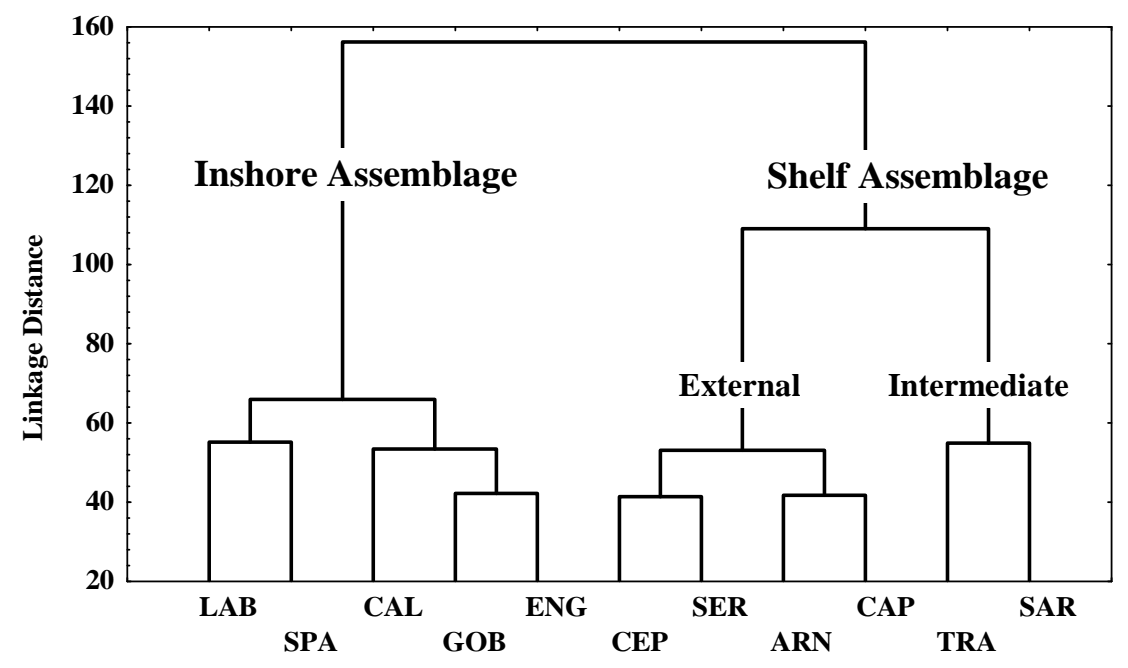

Figure 3 - Dendrogram representing fish larvae assemblages in the Gulf of Cádiz during summer of 1994 and 1995.

In 1994 and 1995 (Table 2), it presented the major taxa number $(\mathrm{p}<0.001)$ and larvae density $(\mathrm{p}<$ 0.001 ). In both years, the gilt sardine (Sardinella aurita) was the dominant species and showed a conspicuous peak of abundance in 1995.

In 1995, the area occupied was smaller than 1994. The external assemblage was located in the midshelf group of stations (Group 3) and was formed by demersal taxa such as Arnoglossus spp, Cepola rubescens, Serranus spp (only in 1995). The mesopelagic Capros aper was presented but always at low densities. In 1994 (Table 2) this assemblage presented the less taxa number ( $\mathrm{p}<$ $0.0001)$ and larvae density ( $<<0.0001)$.

\section{DISCUSSION}

\section{Hydrology}

The horizontal distribution of surface salinity showed interannual changes in both years. In 1994, higher salinities were observed at external sites, though in 1995, higher values were observed at intermediate sites, in front of Cádiz Bay. In 
1995 , the more elevated values of salinity and temperature found in the surroundings of the bay of Cádiz could be explained by the fact to be outside the influence of the Atlantic current coming from Portugal and because 1995, was a particularly dry year, which supported the hypothesis of a greater solar heating and a greater evaporation (Rubín et al., 1999).

In the intermediate layers, however, the topography of $15{ }^{\circ} \mathrm{C}$ isotherms suggested anticyclonic circulation near the continental slope edge (Rubín et al., 1997, 1999). This coincidence of the subsurface circulation with the edge of the continental slope would corroborate the notion that anticyclonic circulation in this area seemed to be a permanent feature in summer time (Garcia et al., 2002).

\section{Between year differences}

There were differences in the abiotic and biotic environment between 1994 and 1995. The interannual differences between surface salinity and ZDV were not significant $(\mathrm{p}>0.05)$. The upper water column was warmer $(\mathrm{p}<0.05)$, in 1994 and had less fish larvae density $(\mathrm{p}<0.01)$. Concurrently, larvae of anchovy (E. encrasicolus) were more abundant in 1994 than in 1995 ( p < 0.05 ). In contrast, larvae of $S$. aurita and Trachurus spp were significantly more abundant in 1995 ( $\mathrm{p}<0.05)$, occupied in the shelf, and were almost absent in the inshore zone. Such distribution was strongly related to bathymetry and imitated adult distribution (Rubín, 1992). Similar interannual differences was observed during summer of 1995-1996, in the northern Aegean Sea (eastern Mediterranean) and was attributed to differences in reproductive strategies among epipelagic fishes (Somarakis et al., 2000).

\section{Larval fish assemblages}

During summer of 1994 and 1995, two larval fish assemblages were distinguished in the Gulf of Cádiz: Inshore and Shelf, primarily related to bathymetry. This was supported by the results of the Kruskal-Wallis Test of water depth among stations group that resulted from numerical classification of larval fish abundance data. Coastal and Neritic ichthyoplankton assemblages were identified in the southern gulf of Mexico (Flores-Coto et al., 2000; Sanvicente-Añorve et al., 1998). Two ichthyoplankton assemblages characterisitics of the Chesapeake Bay plume and inner-continental shelf waters were defined by Reiss and McConaugha (1999).

The "inshore assemblage" occupied the shallow coast area and comprising mainly E.encrasicolus and Gobiidae. The species that characterized this assemblage generally spawn in inshore waters and even in estuaries and inshore lagoons. Gobiid and engraulid larvae too had the highest average density in inshore assemblage of the gulf of Mexico (Flores-Coto et al., 2000; Quintal-Lizama et al., 2000). High engraulid densities area usually associated with river mouths; In the Catalan Sea main spawning areas for anchovy area located in the vicinity of the mouths of Rhône and Ebro rivers (Palomera and Sabatés, 1990). High densities of Engraulis mordax characterize the Columbia river plume assemblage (Doyle et al., 1993). In the Adriatic Sea preferential spawning by anchovies in the region influenced by run-off from the Po river (Coombs et al., 1997).

The area occupied by the inshore assemblage varied depending on the extension of continental waters into the marine environment that was more important in 1994 than 1995 (Rubín et al., 1999). However, the wide larval distribution of these taxa (especially gobies and anchovy), might be a consequence of a high larval drift from the shallow areas where massive spawning occurs. According Thorrold and McKinnon (1995) increased river runoff can expand low-salinity plumes seaward, increasing the spatial distribution of inshore species on the shelf. In the Catalan Sea was observed that although the anchovy larvae are advected away from the spawning area, they remain together in a favourable habitat for their development (Sabatés et al., 2001). In the Chesapeake Bay the inshore upwelling provided the mechanism for rapid transport of the plume to the shelf and was the responsible for the mesoscale spatial pattern and heterogeneity of ichthyoplankton on the shelf (Reiss and McConaugha, 1999).

The "shelf assemblage" was formed by demersal (i.e. Arnoglossus spp ) and epipelagic species (i.e. S. aurita and Trachurus) whose adults live and spawn in the continental shelf. Flores-Coto et al. (1989) reported that the main spawning area corresponds to the inner and mid regions of the shelf. Taxa whose adults are mesopelagic, such as C.aper, was also present in the shelf assemblage. This is not surprising because it was frequent on shelf of Alborán Sea an Gulf of Cádiz (Rubín, 1992; Rubín and Abad, 1994). 
In the Gulf of Mexico (Flores-Coto et al., 1988) and Mediterranean Sea (Sabatés, 1990) highest spawning period occurs in summer. In Gulf of Cádiz the high abundance of fish larvae suggest that summer too coincides with the onset of the reproductive season of many fishes.

The largest differences in larval fish assemblages during both years were found in the inshore-shelf gradient. Results suggested that depth (reflecting the distribution and spawning patterns of adult fish population) was the main factor separating the inshore from shelf assemblage. These results were consistent with other ichthyoplankton studies on continental shelves around the world (Richardson et al., 1980; Young et al., 1986; Sabatés, 1990; Moser and Smith, 1993; Mafalda Jr., 2000; Vidal Peñas, 2001; Doyle et al., 2002; Somarakis et al., 2002).

However, variations in the extension and formation of the subgroups between years was not so obvious, although it could be attributed in general to spawning strategies of adult fishes, the main circulation patterns, the continental waters runoff, and to the oceanographic processes of mixing, which have been relevant factors mentioned by others authors (Richardson et al., 1980; Olivar and Shelton, 1993; Thorrold and McWilliams, 1996; Sanvicente-Añorve et al., 1998; Flores-Coto et al., 2000; Mafalda Jr., 2000). In general, the assemblages defined might be considered indicators for the different environments which they inhabited. Species of the coastal assemblages showed a strong ecophysiological dependence upon the lagoonestuarine systems and the members of the coastal and neritic assemblage were mainly plankitivores related to high primary production (SanvicenteAñorve et al., 1998).

This is, to our knowledge, the first meso-scale, multiespecies ichthyoplankton study in the Gulf of Cádiz and it suggest that interannual variability in assemblage structure during summer may reflect meteorological, physical and biological processes.

\section{ACKNOWLEDGEMENTS}

The authors would like to thank the crew of R/V Francisco de Paula Navarro and many scientists who assisted in collecting samples at the sea and sorted the ichthyoplankton. This study was partly supported by CAPES (Ministry of Education, Brazil) as part of the post doctoral grant (BEX
0762-03-2). Financial support was received from the Instituto Español de Oceanografia (IEO) within the framework of the "Ictio.AlboranCádiz" project.

\section{RESUMO}

Duas amostragens de ictioplâncton foram realizadas durante Julho de 1994 e Julho de 1995, no Golfo de Cádiz, com o objetivo de descrever a composição, abundância, padrões de distribuição e variações interanuais das associações de larvas de peixes. Diferenças interanuais foram encontradas neste estudo. Em 1994 salinidades mais elevadas foram observadas nas estações da plataforma externa, enquanto que, em 1995 os valores mais elevados foram encontrados nas estações da plataforma interna. A coluna de água foi mais quente em 1994 e apresentou menor densidade de larvas de peixes. Durante 1994 Sardinella aurita e Engraulis encrasicolus foram abundantes, porém com localização espacial oposta. Em 1995, a abundância de ambas as espécies foi muito diferente, mas com padrão espacial semelhante. A análise de cluster revelou grupos bem definidos de estações e associações de larvas, primariamente relacionadas com a batimetria. A "associação costeira" ocupou as zonas menos profundas; suas espécies características, vinculadas a sistemas estuarinos, compreenderam principalmente Engraulis encrassicolus e Gobiidae. A "associação de plataforma" esteve formada por larvas cujos adultos habitam a plataforma continental e desovam nesta mesma zona, tais como: Sardinella aurita e Trachurus spp. Variações interanuais na composição e extensão dos subgrupos podem ser atribuídas aos principais padrões de circulação, vazão de águas continentais e as estratégias de desova dos peixes.

\section{REFERENCES}

Abrantes, F. (1990), The influence of the Guadalquivir River on modern surface sediments diatom assemblages: Gulf of Cádiz. Comun. Serv. Geol. Portugal, 76, 23-31.

Ahlstrom, E. H. and Thrailkill, J. R. (1963), Plankton volume loss with time of preservation. Rep. Calif. Coop. Oceanic Fish. Invest., 9, 57-73. 
Coombs, S.; Giovanardi, O.; Conway, D.; Manzueto, L.; Halliday, N. and Barret; C. (1997), The distribution of eggs and larvae of anchovy (Engraulis encrassicolus) in relation to hydrography and food availability in the outflow of the River Po. Acta Adriat., 38, 33-47.

Doyle, M. J.; Morse, W. W. and Kendall Jr., A. W. (1993), A comparision of larval fish assemblages in the temperate zone of northeast Pacific and the northwest Atlantic ocean. Bull. Mar. Sci., 53 : (2), 588-644.

Doyle, M. J.; Mier, K. L.; Busby, M. S. and Brodeur, R. D. (2002), Regional variation in springtime ichthyoplankton assemblages in the northeast Pacific Ocean. Progress in Oceanography, 53, 247-281.

Flores-coto, C.; Sanvicente-añorve, L.; Pineda-lópez, R. and Rodrigues-Valier, M.A. (1989), Composición, distribución y abundancia ictioplanctónica del sur del Golfo de México. Universidade y Ciencia, 5, 65-84.

Flores-coto, C.; Martínez-gutiérrez, R.; González-félix, M.; Sanvicente-Añorve, L. and Zavala-Garcia, F. (2000), Annual variation of ichthyoplankton assemblages in shelf waters of the southern Gulf of Mexico. Caribbean Journal of Science, 36 : (3/4), 233-243.

Folkard, A. M.; Davies, P.; Fiúza, A. F. G. and Ambar, I. (1997), Remotely sensed sea surface thermal patterns in the Gulf of Cádiz and the Strait of Gibraltar: variability, correlations, and relationships with the surface wind field. Journal of Geophysics Research, 102, 5669-5683.

Frank, K. T. and Leggett, W. C. (1983), Multispecies larval fish associations: accident or adaptation. Can. J. Fish. Aquat. Sci., 40, 754-762.

García, A. M. A. and Moyano, P. D. (1991), Estados juveniles de la ictiofauna en los caños de las salinas de la Bahía de Cádiz. Instituto de Ciencias Marinas, Cádiz.

García, C. M.; Prieto, L.; Vargas, M.; Echevarría, F.; García-Lafuente, J.; Ruiz, J. and Rubín, J. P. (2002), Hydrodynamics and the spatial distribution of plankton and TEP in the Gulf of Cádiz (SW Iberian Peninsula). Journal of Plankton Research, 24 : (8), 817-833.

Mafalda Jr., P. (2000), Distribuição e abundância do ictioplâncton da costa norte da Bahia e suas relações com as condições oceanográficas. Tese de Doutorado, Fundação Universidade Federal do Rio Grande.

Moser, H. G. and Smith, P. E. (1993), Larval fish assemblage and oceanic boundaries. Bull. Mar. Sci., 53 : (2), 283-289.

Olivar, P. and Shelton, P. A. (1993), Larval fish assemblages of the Benguela current. Bull. Mar. Sci., 53 : (2), 450-474.

Palomera, I. and Sabatés, A. (1990), Co-occurrence of Engraulis encrassicolus eggs and larvae in the northwestern Mediterranean. Sci. Mar., 54, 61-67.
Pielou, E. C. (1984), The Interpretation of Ecological Data: a Primer on Classification and Ordination. New York: Wiley.

Quintal-Lizama, C. and Vásquez-Yeomans, L. (2000), Associaciones de larvas de peces en una bahía del Caribe Mexicano. Rev. Biol. Trop., 49 : (2), 559-570.

Reiss, C. S. and McConaugha, J. R. 1999. Cross-frontal transport and distribution of ichthyoplankton associated with Chesapeake Bay plume dynamics. Cont. Shelf Res., 19, 151-170.

Richardson, S. L.; Laroche, J. L. and Richardson, M. D. (1980), Larval fish assemblages and associations in the north-east Pacific ocean along the Oregon coast, winter-spring 1972-1975. Estuarine Inshore Shelf. Sci., 11, 671-699.

Rodrigues-Roda, J. (1970), La sardina, Sardina pilchardus, del Golfo de Cádiz. Inv. Pesq., 34 : (2), 451-476.

Rodrigues-Roda, J. (1977), El boquerón, Engraulis encrasicolus, del Golfo de Cádiz. Inv. Pesq., 41 : (2), 523-542.

Rubín, J. P. (1992), El ictioplancton del mar de Alborán. Relación de su distribución espaciotemporal y composición, con diferentes variables ambientales y con la distribución de los peces adultos. Tesis Doctoral, Universidad de Málaga.

Rubín, J. P. and Abad, R. (1994), La presencia masiva ocasional de larvas y adultos de Capros aper en el golfo de Cádiz y mar de Alborán. Revista de Geociencias, 9, 23-26.

Rubín, J. P.; Cano, N; Arrate, P.; García, J.; Escánez, J.; Vargas, M. and Hernández, F. (1997), El ictioplancton, el mesozooplancton y el medio marino en el golfo de Cádiz, estrecho de Gibraltar y sector noroeste del mar de Alborán, en julio de 1994. Inf. Téc. Inst. Esp. Oceanogr., 167, 1-48.

Rubín, J. P.; Cano, N.; Prieto, L.; García, C.; Ruiz, J.; Echevarría, F.; Corzo, A.; Gálvez, J. A.; Lozano, F.; Alonso-Santos, J. C.; Escánez, J.; Juárez, A.; Zabala, L.; Hernández, F.; García Lafuente, J. and Vargas, M. (1999), La estructura del ecosistema pelágico en relación con las condiciones oceanográficas y topográficas en el golfo de Cádiz, estrecho de Gibraltar y mar de Alborán (sector noroeste), en julio de 1995. Inf. Téc. Inst. Esp. Oceanogr., 175, 1-73.

Sabatés, A. (1990), Distribution patterns of larval fish populations in the Northwestern Mediterranean. Mar. Ecol. Prog. Ser., 59, 75-82.

Sabatés, A.; Salat, J. and Olivar, M. P. (2001), Advection of continental water as an export mechanism for anchovy, Engraulis encrassicolus, larvae. Scientia Marina, 65 : (1), 77-87.

Salmerón, F. and Rubín, J. P. (1997a), Cambios interanuales en la composición del ictioplancton nerítico en el Golfo de Huelva. In: Simposio sobre el Margen Continental Ibérico Atlántico, 2. Resumen ... pp. 259. 
Salmerón, F. and Rubín, J. P. (1997b) Estudio comparado de la distribución espacio-temporal de las larvas de boquerón y alacha en el litoral Onubense (1994-1996). In: Simposio sobre el Margen Continental Ibérico Atlántico, 2. Resumen ... pp. 263.

Sanvicente-Añorve, L.; Flores-Coto, C. and SánchezVelasco, L. (1998), Spatial and seasonal patterns of larval fish assemblages in the southern Gulf of Mexico. Bull. Mar. Sci., 62 : (1), 17-30.

Siegel, S. (1982), Estadística non paramétrica. México: Editorial Trillas.

Smith, P. E. and Richardson, S. L. (1979), Técnicas modelo para prospecciones de huevos y larvas de peces pelágicos. FAO Doc. Téc. Pesca, 175, 1-107.

Somarakis, S.; Maraveya, E. and Tsimenides, N. (2000), Multispecies ichthyoplankton associations in epipelagic species: is there any intrinsic adaptive function ? Belg. J. Zool., 130 : (1), 125-129.

Somarakis, S.; Drakopoulos, P. and Filippou, V. (2002), Distribution and abundance of larval fish in the northern Aegean Sea - eastern Mediterranean - in relation to early summer oceanographic conditions. Journal of Plankton Research, 24 : (4), 339-357.

Stevenson, R. E. (1977), Huelva front and Malaga, Spain, eddy chain as defined by satellite and oceanographic data. Deutsche Hydrophisce Zeilschrifl., 30, 51-53.

Taylor, L. R. (1961), Aggregation, variance and the mean. Nature, 189, 732-735.

Thorrold, S. R. and McKinnon, A. D. (1995). Response of larval fish assemblages to a riverine plume in inshore waters of Central Great Barrier Reef Lagoon. Limnology and Oceanography, 40 : (1), 177-181.
Thorrold, S. R. and McWilliams, D. B. (1996) Mesoscale distribution patterns of larval and pelagic juvenile fishes in the central Great Barier Reff lagoon. Mar. Ecol. Prog. Ser., 145, 17-31.

Vargas, M. J.; García-Lafuente, J.; Delgado, J. and Criado, F. (2003), Seasonal and wind-induced variability of sea surface temperature patterns in the Gulf of Cádiz. Journal of Marine Systems, 3, 205-219.

Vidal Peñas, I.; López Castejón, F. and Mas Hernández, J. (2001), Influencia de la topografía submarina sobre la distribución de las comunidades de ictioplancton en el entorno de la reserva marina de cabo de Palos islas Hormigas (sudeste ibérico). Bol. Inst. Esp. Oceanog., 17 : (1/2), 129-135.

Young, P. C.; Leis, J. M. and Hausfeld, H. F. (1986), Seasonal and spatial distribution of fish larvae in waters over the north west continental shelf of western Australia. Mar. Ecol. Progr. Ser., 31, 209-222.

Received: September 24, 2004; Revised: December 28, 2004; Accepted: August 05, 2005. 